\title{
The Expansion of Higher Education and the Returns of Distance Education in China
}

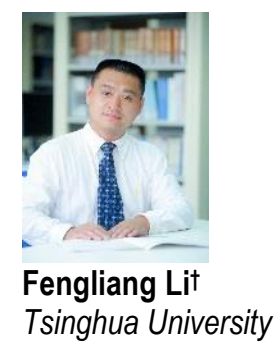

\begin{abstract}
The returns of traditional face-to-face education are widely analyzed, but there is a need for empirical studies on the returns of distance education. Further, comparative studies on returns of both traditional and distance education using high-quality data are rare. Since 1999, continuous and rapid expansions have occurred in the whole Higher Education system in China. Given this background, what are the changes in returns of both traditional face-to-face education and distance education? This study analyzes the returns of both of these formats from 2003 to 2006 using the data from the China General Social Survey Open Database (Chinese General Social Survey [CGSS], 2018), adding educational background as a dummy variable to the Mincerian income equation. The empirical results show that Distance Higher Education can significantly increase the income of learners, the returns of distance education are lower than those of traditional face-to-face education and that from 2003 to 2006, the returns of distance education decrease dramatically.
\end{abstract}

Keywords: distance higher education, returns of education, expansion of education, China 


\section{Introduction}

Human capital theory sees education as an investment in human capital and regards that education can bring economic benefits to learners as well as promote national economic growth (Becker, 1964; Schultz, 1961). Since the 1950s there have been many studies on the private benefits of education, covering almost every nation and area (Daly, Lewis, Lewis, \& Heaslip, 2015; Hartog \& Gerritsen, 2016; Heckman, Lochner, \& Todd, 2003; Psacharopoulos \& Patrinos, 2004). These studies test the statement in human capital theory that education improves individual productivity. Further, private returns of education have become a main factor for individuals and families to make decisions in education investment. For example, comparing the returns of education and returns of other forms of capital investment can indicate whether education is a worthy investment (Psacharopoulos \& Patrinos, 2004).

There are two prevalent methods for measuring the private returns of education (Psacharopoulos \& Patrinos, 2004). One is the Mincerian rate of return, namely marginal returns to education, which reflects the increased benefit caused by one more year of education. The other method for measuring private returns of education is the internal rate of return, which calculates the discount rate that equalizes the real costs of education during the period of study to the real gains made as a consequence of this study period. Due to the availability of the cost data, most empirical studies estimate the Mincerian rate of return to education.

One important reason for establishing distance education institutes and providing distance education programs is to promote the development and investment of human capital. There is enough evidence which shows that distance education can improve professional skills and promote learners' employment in both developed countries and developing countries (Azeiteiro, Bacelar-Nicolaua, Caetano, \& Caeiro, 2015; Siaciwena, 2008). Distance education, with face-to-face schooling, has become an important subsystem of the whole educational system. However, the studies of private returns of education still focus on traditional schooling and training. There are few empirical studies into the private returns of distance education. Although there are many studies on the costs of distance education, there are relatively fewer studies on the benefits or returns of distance education (Bramble \& Panda, 2008; Moore, 2013; Rumble, 2001, 2004). The content of two books illustrates this point, namely Rumble's (2004) book titled Papers and Debates on the Economics and Costs of Distance and Online Learning and Bramble and Panda's (2008) book titled Economics of Distance and Online Learning. Both books contain many chapters on the costs of distance education but only two chapters focus on the benefits. Although some scholars have discussed the benefits (Bartolic-Zlomislic \& Bates, 1999a, 1999b; Bates, 1995; Cukier, 1997; Hülsmann, 1997), empirical studies are lacking, as most of the existing studies do not measure the real benefits or returns of distance education. They lack in comparing the real income between those who have received distance education and those who have not received distance education. This situation is not in accordance with the current development of distance education, since the differences of real income after receiving distance education will be a good index for learners to decide whether to invest in distance education.

There are three empirical studies on the returns of distance education, all based on distance education in Mainland China. Li, Xia, Zhao, and Zhang (2009), Ni, Xu, Liang, and Zhu (2011), and Zheng, Chen, and Zhang (2009) reached similar conclusions that distance education can bring positive economic benefits. 
These three studies used the Mincerian income equation to estimate the return of distance education according to a learner's income, educational background, and working experience (Li, Xia, Zhao, \& Zhang, 2009; Ni, Xu, Liang, \& Zhu, 2011; Zheng, Chen, \& Zhang, 2009). All three studies, however, have the same three shortcomings. First, the sample cases are in-school learners in distance education institutes and the data are not the real cross-section data, which thereby does not meet the assumption of the Mincerian income equation. Second, the sample cases are from one or two Distance Higher Education institutes, and there are problems with generalizability. Third, only sample cases from Distance Higher Education are used, which therefore does not provide a credible comparison. Thus, data of higher quality, wider coverage, and more representation needs to be studied.

Since 1999, the whole Higher Education system in China has been in continuous and rapid state of expansion (Li, Morgan, \& Ding, 2008). The scale of this expansion is likely to lead to changes in the returns of education (Psacharopoulos \& Patrinos, 2004). Thus, with the expansion, what are the changes of returns of Distance Higher Education? This is important information that individuals and institutions should know.

Given these considerations, this study uses representative data, with wide coverage and rigorous sampling methods to analyze the change trend of private returns of Distance Higher Education. Further, this study compares the changing trend of returns of Distance Higher Education and Traditional Higher Education. Hence this study aims to make two main contributions. First, it is the first study (to our knowledge) to use high-quality and representative data to estimate the private returns of Distance Higher Education. That is, it is the first to measure the real income benefits of distance education. As such it will improve academic understanding of distance education as human capital and promote the study of the economics of distance education. Second, under the background of Higher Education expansion, the study will uncover trends in the changing returns of Distance Higher Education. This has the potential to guide investments regarding distance education, and help institutes plan how to develop and implement programs.

The next section of this paper introduces the expansion of Higher Education in China and the development of Distance Higher Education. The third section introduces the research methods and data. The fourth section presents the empirical results. The fifth section discusses the findings, and the final section offers a brief conclusion.

\section{Literature Review: The Expansion of Higher Education and the Development of Distance Higher Education in China}

At the beginning of the 1950s in Mainland China, distance education developed from correspondence education. In need of more high-quality human resources after the reform and opening up in 1978, Deng Xiaoping, who was the core of the "second generation" of Chinese leadership, put forward the idea that "planning for the development of modern educational instruments such as television and broadcast is an important way of rapidly developing China's education" (MOE, China, 1999). This initiated the establishment of Radio and Television Universities and the rapid growth of Distance Higher Education (MOE, China, 1999). From 1983, Radio and Television Universities started to enroll students from junior college education (Ding, 2001). By 1985, the number of junior college students attending Radio 
and Television Universities reached 674,000, accounting for $40 \%$ of Higher Education students in China (Ding, 2001).

In 1999, the Chinese Government decided to expand Higher Education drastically, and in 2003, the enrolment ratio of Higher Education reached 17\% (Li, Zhou, \& Fan). According to Martin Trow's theory of Higher Education Massification (1973), Chinese Higher Education had thereby surpassed the 15\% threshold for characterization as Mass Higher Education.

Since 1999 in China, the expansion of Higher Education included both Traditional and Distance Higher Education. In order to promote the expansion of Distance Higher Education in 1998, China's Ministry of Education decided to allow some traditional universities to provide Distance Higher Education, and further to permit Tsinghua University ${ }^{i}$, Zhejiang University, Beijing University of Posts and Telecommunications, and Hunan University to launch Distance Higher Education. In 2000, the Ministry of Education decided to take advantage of information network technology and infrastructure construction to further expand the traditional universities to launch distance education, and thirty more traditional universities were qualified to provide Distance Higher Education (Ding, 2001). Until 2008, the Ministry of Education qualified sixty-eight traditional universities to provide academic credentials education in the form of distance education (MOE, China, 2009). As a result of these reforms, the number of distance education students increased rapidly to 2,723,715 (MOE, China, 2009).

In 2011 the Ministry of Education eventually decided to establish the Open University of China based on Radio and Television Universities (Open University of China, 2016). The Open University of China engages in promoting education innovation, sharing high-quality education resources, and enhancing educational equity (http://en.ouchn.edu.cn/index.php/about-v2/new-style-university). In 2012, the number of registered students reached 3.59 million, including 1.05 million undergraduates, 2.54 million junior college students, 200,000 peasants, 100,000 soldiers, and 6,000 disabled students (http://en.ouchn.edu.cn/index.php/about-v2/new-style-university).

Today, China's Distance Higher Education system is mainly made up of the Open University of China (originally the Radio and Television University system) and the online education programs of traditional research universities. In addition, a few independent correspondence institutions also provide small-scale Distance Higher Education.

Given such background, what are the changes of the returns of Traditional Higher Education and Distance Higher Education? The following analyses will estimate the returns using the Mincerian income equation based on large-scale and high-quality individual cross-section data from different years.

\section{Method and Data}

This study mainly uses the Mincerian income equation to estimate the returns of distance and traditional education. The Mincerian income equation was proposed by an economist, Jacob Mincer, one of the founders of human capital theory (Mincer, 1974) as: 


$$
\operatorname{Ln} Y=\alpha+\beta * S+\gamma_{1} * E X+\gamma_{2} * E X^{2}+\xi
$$

Figure 1. In this, $\mathrm{Y}$ is individual's income, $\mathrm{LnY}$ is the natural logarithms of individual's income, $\alpha$ is a constant term, $\mathrm{S}$ is the years of schooling of individual, EX is the years of working experience of individual worker in the labour market, and $\xi$ is the error term.

Calculating the partial derivative of the equation above gives:

$$
\beta=\frac{\partial \ln Y}{\partial S}=\frac{\partial Y / \partial S}{Y} \approx \frac{\Delta Y / Y}{\Delta S}
$$

Figure 2. In this, $\beta$ is individual's increasing rate caused by one more year's education. In economic studies, $\beta$ stands for the percentage increase of an individual worker's income by taking one more year of education, which is named Mincerian rate of return.

Some scholars add the educational degree instead of educational years as a dummy variable in the Mincerian income equation (Carnoy, 1995). With this formulation, the coefficient difference of the educational degree is used to estimate the increasing rate of the individual's income (Carnoy, 1995). This method can only get the approximate value of return of education, which is not exactly equal to the value calculated by the Mincerian income equation ${ }^{\mathrm{ii}}$.

This study uses sample cases' income, educational background, and working years to estimate returns, by adding the dummy variables of educational degree to the standard Mincerian income equation.

All the data are from the China General Social Survey (CGSS; http://www.chinagss.org/). The first general social survey was conducted in China with the cooperation of the Sociology Department of Renmin University of China and the Social Research Center of Hong Kong University of Science and Technology. The survey adopts strict sampling technologies, and it is the first nationwide, comprehensive, continuous, and non-governmental social research survey, with 125 county units, 559 neighborhood committees, 5,900 interviewees, and 5,894 valid sample cases. Since 2005, the survey project team issued CGSS via Internet, and the data of CGSS in 2003 are public and free worldwide. The data of CGSS have gradually become public including the data of 2003, 2005, 2006, and 2008. The sampling of the year 2003, 2005, and 2006 are identical and there is a dramatic change in the sample size in 2008. In order to guarantee the comparability of the empirical results, this study uses the data in 2003,2005 , and 2006 for analyses.

In the studies by Zheng, Chen, and Zhang (2008), Li et al. (2009) and Ni et al. (2011), the data used includes only in-school Distance Higher Education learners. Compared with these studies, this study has an advantage that the data used includes adults of in-school learners and individuals in the labor market with various educational levels. In order to make the return of distance education more precise, this study analyzes only those individuals in the labor market.

Since the late 1970s, distance education in China has mainly focused on junior college education and undergraduate education, and rarely focused on post-graduate education ( $\mathrm{Li} \& \mathrm{Fu}, 2015$ ). Thus, Distance Higher Education is restricted to distance junior college and undergraduate education in this study. In order to estimate the return of Distance Higher Education, the laborers with the highest degree of senior secondary education should be the reference group. Therefore, the sample cases selected for 
this study were individual laborers with the educational level of senior secondary education, junior college education, and undergraduate education respectively.

Junior college education can be divided into full-time and part-time, similar to undergraduate education. In the SPSS data files provided by CGSS, "part-time" is defined as "The learners receive education from adult university, correspondence university, Radio and Television University. Most learners are still in the labor market and they take the courses in the evenings and weekends and faceto-face is not the main teaching method." Obviously, the "part-time" can be deemed as distance education.

Table 1

Educational Backgrounds of Sample Cases

\begin{tabular}{|l|c|c|c|}
\hline \multicolumn{1}{|c|}{ Educational Background } & 2003 & 2005 & 2006 \\
\hline Senior secondary education & 1362 & 1640 & 1284 \\
\hline Distance college & 364 & 243 & 271 \\
\hline Traditional college & 262 & 355 & 203 \\
\hline Distance undergraduate & 85 & 73 & 80 \\
\hline Traditional undergraduate & 204 & 209 & 176 \\
\hline Total & 2277 & 2520 & 2014 \\
\hline
\end{tabular}


Table 2

The Simple Statistical Description of Variables

\begin{tabular}{|c|c|c|c|c|c|c|}
\hline \multirow[b]{2}{*}{ Variables } & \multicolumn{2}{|c|}{2003} & \multicolumn{2}{|c|}{2005} & \multicolumn{2}{|c|}{2006} \\
\hline & Mean & $\begin{array}{l}\text { Standard } \\
\text { Deviation }\end{array}$ & Mean & $\begin{array}{l}\text { Standard } \\
\text { Deviation }\end{array}$ & Mean & $\begin{array}{l}\text { Standard } \\
\text { Deviation }\end{array}$ \\
\hline Ln (income) & 9.001 & 0.853 & 9.129 & 0.873 & 9.258 & 0.823 \\
\hline Distance college & 0.089 & 0.284 & 0.050 & 0.218 & 0.073 & 0.260 \\
\hline Traditional college & 0.064 & 0.244 & 0.073 & 0.260 & 0.055 & 0.227 \\
\hline Distance undergraduate & 0.021 & 0.142 & 0.015 & 0.121 & 0.021 & 0.145 \\
\hline Traditional undergraduate & 0.050 & 0.217 & 0.043 & 0.202 & 0.047 & 0.212 \\
\hline Working experience & 24.954 & 12.702 & 26.640 & 15.124 & 24.821 & 13.592 \\
\hline Working experience square & 783.989 & 685.149 & 938.396 & 911.329 & 800.786 & 719.777 \\
\hline $\mathrm{N}$ & & 2277 & & 2520 & & 2014 \\
\hline
\end{tabular}

The sample cases can be categorized into five kinds, including senior secondary education, distance college, face-to-face/traditional college, distance undergraduate, and face-to-face/traditional undergraduate. The sample cases with no information of annual income and working experience are excluded. Table 1 shows the distribution of the educational background of the sample cases.

The study deems those with senior secondary education as the reference group, and the other four educational levels as the dummy variables added to the Mincerian income equation. Table 2 is the simple statistical description of various variables.

\section{Empirical Results}

Table 3 depicts the regression of the Mincerian income equation in each year. Figure 3 shows the tendency of returns of distance education and traditional education of different educational levels from 2003 to 2006. 
Table 3

The Regression of Mincerian Income Equation

\begin{tabular}{|c|c|c|c|}
\hline \multirow{2}{*}{ Distance college } & 2003 & 2005 & 2006 \\
\hline \multirow{2}{*}{ Traditional college } & $0.396^{* * *}$ & $0.33^{* * *}$ & $0.310^{* * *}$ \\
\cline { 2 - 4 } & $(0.044)$ & $(0.050)$ & $(0.048)$ \\
\cline { 2 - 4 } & $0.400^{* * *}$ & $0.446^{* * *}$ & $0.407^{* * *}$ \\
\hline \multirow{2}{*}{ Distance undergraduate } & $(0.050)$ & $(0.043)$ & $(0.056)$ \\
\cline { 2 - 4 } & $(0.083)$ & $(0.086)$ & $(0.083)$ \\
\hline \multirow{2}{*}{ Traditional undergraduate } & $0.873^{* * *}$ & $0.749^{* * *}$ & $0.680^{* * *}$ \\
\cline { 2 - 4 } & $(0.056)$ & $(0.054)$ & $(0.060)$ \\
\hline Adjusted R square & 0.134 & 0.110 & 0.102 \\
\hline $\mathrm{N}$ & 2277 & 2520 & 2014 \\
\hline
\end{tabular}

Note. The dependent variable is the natural logarithms of an individual's annual income. Standard errors are presented in parentheses. “***”: significant at the $1 \%$ level. The coefficient information of the variables of constant, working experience, and its square are omitted.

From Table 3 and Figure 3 it can be seen, first, that the coefficients of the four education dummy variables are positive and significant, irrespective of distance education or traditional education, junior college education, or undergraduate education. The significance level is $\mathrm{p}<0.01$. This reveals that both Distance Higher Education and Traditional Higher Education can significantly improve learners' income. 


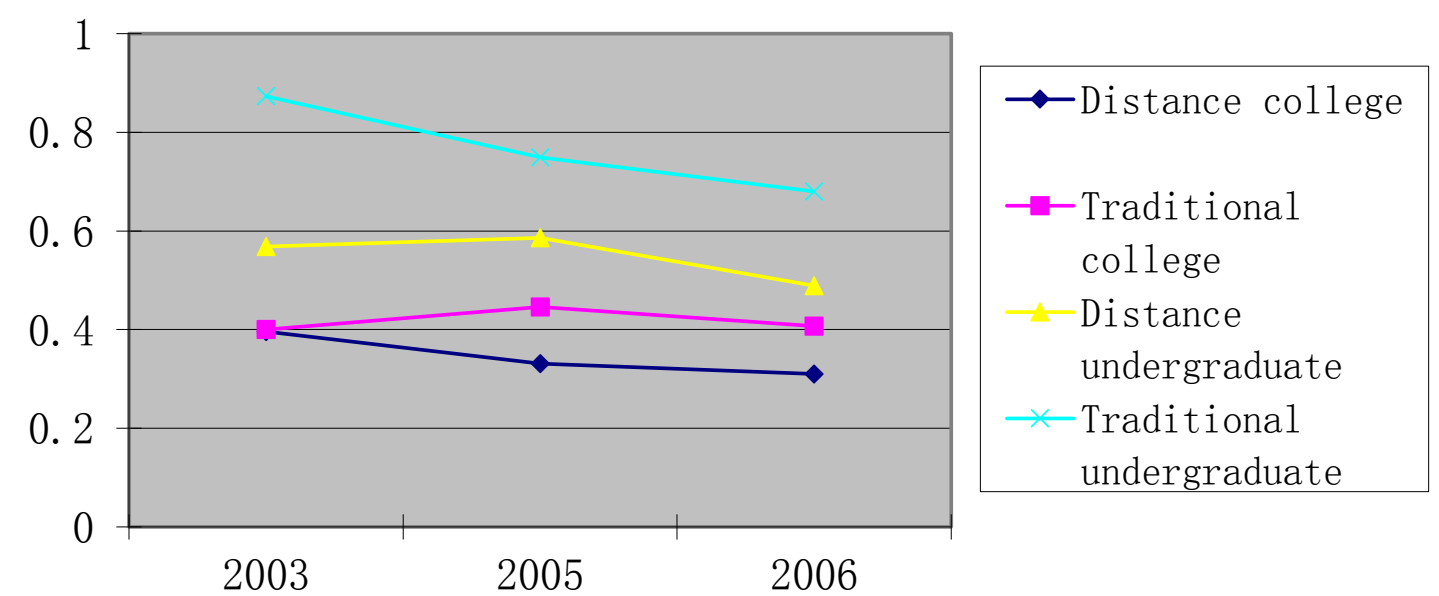

Figure 3. The change of returns of distance and traditional education from different educational degrees.

Secondly, the returns of distance education are lower than that of traditional education. It reveals that although both distance and traditional education can increase learners' income significantly, compared to face-to-face education, distance education has a smaller effect on increasing learners' income.

There are many possible explanations why the economic benefit of distance education is lower than that of face-to-face education. For example, distance education provides more flexibility and convenience for the learner, thus potentially attracting students who may be unable (due to work or life commitments) to study full-time at a campus university. With this, the lower economic returns of distance education may not be due to distance education itself but the result of the learners' extracurricular work or life commitments/inability to study full time. Such explanations are beyond the focus of this paper, but it would be helpful for follow-up research to investigate.

Thirdly, the difference of returns of distance education versus traditional education can be determined at different educational levels by dividing the coefficient of traditional education by that of distance education. Both in 2003 and 2006, the difference of undergraduate education is bigger than that of junior college education. This means that the return of distance education is lower than that of traditional education, and the disparity is more apparent at the level of the bachelor's degree.

Lastly, when looking to Figure 3, the returns of distance college, distance undergraduate, and traditional undergraduate education appears to decline each year, suggesting that the returns of these forms of education have a declining tendency. This tendency is consistent with another empirical study (Ding, $\mathrm{Yu}, \& \mathrm{Yu}, 2012)$. This tendency also contrasts the dramatic increase of returns of Higher Education between 1990 and the early $21^{\text {st }}$ century (Chen, Chen, \& Xia, 2003; He, 2009; PKU GSE, 2005). This shows that the expansion of Higher Education is accompanied by declined returns of Higher Education.

\section{Discussion}

This paper has found that Distance Higher Education can apparently increase learners' income. The coefficients of distance junior college education are about $31 \%$ to $40 \%$ and the coefficients of distance 
undergraduate education are about $49 \%$ to $59 \%$. These results suggest that investing in Distance Higher Education is a sound choice. However, the returns of Distance Higher Education have declined, and fall behind that of Traditional Higher Education. The whole Higher Education system in China, especially post-graduate education, is in a continuous state of expansion. (Li, Yuan, \& Liu, 2008; Yang \& Li, 2012). Thus, the returns of junior college education and undergraduate education are likely to decline, and the Distance Higher Education system currently is not qualified to provide post-graduate education. Thus, the reformation of Distance Higher Education might be expected.

Currently, Distance Higher Education in China does not have a positive reputation. The People's Daily, the most authoritative official newspaper, once published several articles criticizing Distance Higher Education in China ${ }^{\text {iii. }}$. This is a fraught situation for Distance Higher Education. With the expansion of Higher Education, it is rather easier for people to access Traditional Higher Education. Once the return of Distance Higher Education loses its charm, Distance Higher Education it is likely to face further threats and the need to find new rationales, methods, and markets. This should be recognized by the related administrative sectors and providers in the Distance Higher Education system. While Distance Higher Education has continued to flourish in more mature Higher Education systems in Europe and North America, it has done so by embracing new teaching technologies, new "mature age" (non-schoolleaver) students, and professional development markets.

\section{Conclusion}

There are plenty of studies on returns of traditional education. Although the economic targets of distance education are to improve learners' skills and to promote their employment (Azeiteiro et al., 2015; Siaciwena, 2008) studies on returns of distance education are fewer, due to the difficulties to obtain data, and the ease of the economic target to be neglected. To fill this gap this study has used large-scale and high-quality data spanning several years to estimate the returns of Traditional and Distance Higher Education from 2003 to 2006, adding education background as a dummy variable to the standard Mincerian income equation.

The empirical results show that as with Traditional Higher Education, Distance Higher Education can significantly improve learners' income. For distance junior college learners, the increase is about $30 \%$ to $40 \%$, and for distance undergraduate learners the increase is about $50 \%$ to $60 \%$. This reveals that Distance Higher Education is a thoroughly valuable human capital investment. Although the returns of Distance Higher Education are impressive, these returns are apparently lower than those of traditional education, especially in the level of undergraduate education. With the expansion of Higher Education, the returns of Distance Higher Education have a declining tendency.

Based on the empirical results above, this paper suggests that the Distance Higher Education system in China should address this potential looming crisis, especially given that the changing population structures and lowering birth rates are likely to convey further decline (Yang \& Li, 2012).

In further research, more attention should be paid to the following three areas. First, the returns of different majors of distance education can be estimated to better guide learners in how to choose majors. Second, the impact of educational quality on the returns of Distance Higher Education can be analyzed since many empirical studies show that quality will increase the returns of traditional face-to-face 
Higher Education (Hanushek, Ruhose, \& Woessmann, 2015; Hanushek \& Woessmann, 2012; Jackson, Johnsonand, \& Persico, 2016). Third, there are few empirical studies on the private returns of distance education and fewer empirical studies on the social returns of distance education. Distance education helps learners gain private benefits, and more importantly, it can improve the development of society with high social benefits. Thus, further studies should be conducted to estimate the social returns of distance education.

\section{Acknowledgements}

This article was supported by "The basic research project of young teachers of independent research program of Tsinghua University" (NO.: 20151080456). It is also supported by "An empirical study on improving the equity by online education in China" project (NO.: 2016YB103) and was sponsored by The Online Education Research Fund of Ministry of Education Online Education Center (Quantong Education Fund).

The author wishes to thank Professor Tony Bates, Sir John Daniel, Professor Rory McGreal, Professor Geraint Johnes, Professor Hamish Coates and two anonymous reviewers for their helpful comments on earlier drafts. 


\section{References}

Azeiteiro, U. M., Bacelar-Nicolaua, P., Caetano, F., \& Caeiro, S. (2015). Education for sustainable development through e-learning in higher education: Experiences from Portugal. Journal of Cleaner Production, 106(1), 308-319. Retrieved from https://www.sciencedirect.com/science/article/pii/So959652614012505

Bates, T. (1995). Technology, open learning and distance education. London \& New York: Routledge.

Bartolic-Zlomislic, S., \& Bates, T. (1999a). Investing in on-line learning: Potential benefits and limitations. Canadian Journal of Communication, 24(3), 349-366. Retrieved from https://www.cjc-online.ca/index.php/journal/article/view/1111/1017

Bartolic-Zlomislic, S., \& Bates, T. (1999b). Assessing the costs and benefits of telelearning: A case study from the University of British Columbia. Developing and Applying a Cost-Benefit Model for Assessing Telelearning Project Report. Retrieved from http://www.c3l.unioldenburg.de/cde/econ/readings/bates99.pdf

Becker, G. S. (1964). Human capital: A theoretical and empirical analysis, with special reference to education. New York, NY: Columbia University Press.

Bramble, W. B., \& Panda, S. (2008). Economics of distance and online learning: Theory, practice and research. London, UK: Routledge.

Carnoy, M. (1995). Rates of return to education. In M. Carnoy (Ed.), International encyclopedia of economics of education (2nd ed.; pp.364-369). Oxford, UK: Pergamon Press and Elsevier Science.

Chinese General Social Survey. (2018). Overview. Retrieved from http://www.chinagss.org/index.php?r=index/introduce

Chen, X. Y., Chen, L. K., \& Xia, C. (2003). Rates of return to schooling in urban China: Changes in the 1990s. Peking University Education Review, 1(2), 65-72. DOI: 10.19355/j.cnki.16719468.2003.02.011.

Cukier, J. (1997). Cost-benefit analysis of telelearning: Developing a methodology framework. Distance Education, 18(1), 137-152. Retrieved from https://www.tandfonline.com/doi/pdf/10.1080/0158791970180110

Daly, A., Lewis, P., Lewis, M., \& Heaslip, T. (2015). The private rate of return to a university degree in Australia. Australian Journal of Education, 59(1), 97-112. DOI:10.1177/0004944114565117.

Ding, X. F. (2001). The Stages of Development, Prosperity And Adjustment of Distance Education in China. Modern Distance Education, 17(2), 6-9.

Ding, X. H., Yu, H. X., \& Yu, Q. M. (2012). Private returns to different educational levels in urban China: 2002-2009. Peking University Education Review, 9(3), 73-84. DOI: 10.19355/j.cnki.1671-9468.2012.03.008. 
Hanushek, E. A., Ruhose, J., \& Woessmann, L. (2015). Human capital quality and aggregate income differences: Development accounting for U.S. states (National Bureau of Economic Research Working Paper No. 21295). Retrieved from http://www.nber.org/papers/w21295

Hanushek, E. A., \& Woessmann, L. (2012). Do better schools lead to more growth? Cognitive skills, economic outcomes, and causation. Journal of Economic Growth, 17(4), 267-321. Retrieved from http://hdl.handle.net/10.1007/s10887-012-9081-x

Hartog, J., \& Gerritsen, S. (2016). Mincer earnings functions for the Netherlands 1962-2012. De Economist, 164(3), 235-253. DOI: 10.1007/s10645-016-9279-y

He, Y. M. (2009). The changes of the rate of return to education: An empirical study based on the data of CHNS. Chinese Journal of Population Science, 22(2), 44-54.

Heckman, J. J., Lochner, L. J., \& Todd, P. E. (2003). Fifty years of Mincer earnings regressions (National Bureau of Economic Research Working Paper No. 9732). Retrieved from http://www.nber.org/papers/w9732

Hülsmann, T. (1997). Literature review on cost-effectiveness in ODL systems. International Research Foundation for Open Learning. Retrieved from http://isg.urv.es/publicity/isg/projects/20022005 bff/litrevrpt.pdf

Jackson, C. K., Johnson, R. C., \& Persico, C. (2016). The effects of school spending on educational and economic outcomes: Evidence from school finance reforms. Quarterly Journal of Economics, 131(1), 157-218. https://academic.oup.com/qje/article/131/1/157/2461148

Li, F. L., \& Fu, X. Y. (2015). Is China's online graduate education ready: Based on the analysis of "Online Graduate Education" in USA? Open Educational Research, 21(2), 49-54. DOI: 1007 $-2179(2015) 02-0049-07$.

Li, F. L., Morgan, W.J., \& Ding, X. H. (2008). The expansion of higher education, employment and over-education in China. International Journal of Educational Development, 28(6), 687-697. DOI: 10.1016/j.ijedudev.2007.10.002.

Li, F. L., Xia, G. S., Zhao, X. H., \& Zhang, S. G. (2009). An empirical study on the rates of return to distance higher education: Evidence from students in Nanjing Radio \& TV University and Haerbing Radio \& TV University. Open Educational Research, 15(3), 10-15. DOI: 100722179 (2009) 0320010206

Li, F. L., Yuan, B. T., \& Liu, H. Q. (2008). The forecast of the scale of post-graduate enrolment in China: From an international comparative perspective. Journal of Higher Education, 29(5), 50-56. DOI: 100024203 (2008) 0520050207

Li, F. L., Zhou, M. Y., \& Fan, B. L. (2014). Can distance education increase educational equality?-Evidence from the expansion of Chinese Higher Education. Studies in Higher Education, 39(10), 1811-1822. DOI: 10.1080/03075079.2013.806462

Mincer, J. (1974). Schooling, experience and earnings. New York, NY: Columbia University Press. 
MOE, China. (1999). The opinion on the development of China's modern distance education. MOE. Retrieved from http://www.xrtvu.com/office/oldfile/2002/01/04/AA480822-Fo67-41749821-2760D5A258FC/Index.htm

MOE, China. (2009). The notice on the academic credentials education enrolment work for distance education pilot universities in 2009. MOE. Retrieved from http://www.moe.gov.cn/srcsite/A07/moe 743/200903/t20090328 110176.html

Moore, M. D. (2013). Handbook of distance education (3rd ed.). London \& New York: Routledge.

Ni, Q. R., Xu, H. J., Liang, Z. G., \& Zhu, M. L. (2011). An empirical study of mincerian rate of return to higher distance education: An example of undergraduates in Ningbo Radio \& TV University. Journal of Ningbo Radio \& TV University, 8(2), 73-76.

Open University of China. (2016). "13th five-year plan" reform and construction of the open university of China. Retrieved from http://www.ouchn.edu.cn/News/ArticleDetail.aspx?ArticleId=9c549df3-f111-43c8-aado$\underline{\text { f6352f } 179033 \& \text { ArticleType }=2}$

PKU GSE. (2005). Education and employment survey of Chinese urban residents in 2004 (a). PKU GSE Newsletter 092.

Psacharopoulos, G., \& Patrinos, H. A. (2004). Returns to investment in education: A further update. Education Economics, 12(2), 111-134. Retrieved from https://www.tandfonline.com/doi/abs/10.1080/0964529042000239140

Rumble, G. (2001). The costs and costing of networked learning. Journal of Asynchronous Learning Networks, 5(2), 75-96. Retrieved from http://www.c3l.unioldenburg.de/cde/media/readings/rumbo1d.pdf

Rumble, G. (2004). Papers and debates on the economics and costs of distance and online learning. Oldenburg: Bibliotheks- und Informationssystem der Carl von Ossietzky University. Retrieved from http://www.c3l.uni-oldenburg.de/cde/rumble.pdf

Schultz, T. W. (1961). Investment in human capital. American Economic Review, 51(1), 1-17. Retrieved from https://www.jstor.org/stable/1818907

Siaciwena, R. (2008). Distance education/learning. In McCulloch, G., \& Crook, D. (Eds.), The routledge international encyclopedia of education (pp.175-178). London, UK: Routledge.

Trow, M. (1973). Problems in the transition from elite to mass higher education. California, USA: Carnegie Commission on Higher Education.

Yang, Z. J., \& Li, F. L. (2012). The forecast of the scale of distance higher education in China. China Educational Technology, 32(8), 35-39. DOI: 1006-9860（2012） 08-0035-05.

Zheng, Q. H., Chen, G, \& Zhang, X. D. (2009). Individual return ratio of education investment for distance education. Journal of Beijing Normal University (Social Sciences), 46(02), 99-105. 
${ }^{\dagger}$ Dr. Li Fengliang, Associate Professor (Tenure), Institute of Education, Tsinghua University, Beijing, China. Postcode: 100084; email: dagger@tsinghua.edu.cn. Dr. Li Fengliang, a 2015 CCSEP (CANADA-CHINA SCHOLAR EXCHANGE

PROGRAMME) visiting scholar at Athabasca University, with the support of Foreign Affairs, Trade and Development Canada.

${ }^{i}$ In 2004, Tsinghua University announced that it would stop providing academic credentials education via distance education.

ii The reader who are interested in the rate of return to education can read Carnoy (1995) to understand the difference between the two different methods.

iii Those reader who have interests can read the two review articles on the chaos on the distance higher education in the

"People"s Daily" May-2-2013 (Chinese version). Although some of arguments from these two articles are debatable, but the worrying of Chinese distance higher education's quality is a consensus for many people.

\section{Athabasca}

University

(c) () 